[Review Paper]

\title{
Adsorption and Desorption Simulation of Carbon Canister Using $n$-Butane as Model Compound of Gasoline
}

\author{
${\text { Kazunari } \mathrm{SATO}^{\dagger 1) *} \text { and Noriyuki KoBAYASHI }}^{\dagger 2}$ \\ †1) Technical Center, MAHLE Filter Systems Japan Corp., Shimo-akasaka 591, Kawagoe, Saitama 350-1155, JAPAN \\ $\left.{ }^{2}\right)$ Dept. of Chemical Engineering, Nagoya University, Furo-cho, Chikusa-ku, Nagoya 464-8603, JAPAN
}

(Received November 4, 2010)

\begin{abstract}
Evaporation of fuel gas from the fuel tank of a gasoline vehicle into the atmosphere is strictly controlled by regulations because the gas includes materials highly toxic to human health. Therefore, vehicles are equipped with an evaporative loss control device, of which one of the major parts is a carbon canister filled with activated carbon. Evaporation of fuel gas into the air can be prevented by adsorption/retention in the activated carbon during parking and by desorption/combustion during driving. This paper presents the use of Computational Fluid Dynamics (CFD) for the numerical evaluation of $n$-butane adsorption, desorption, and diffusion in the carbon canister. Such transient phenomena require huge calculation times even using high-end computing resources. Therefore, a unique method was used for the solution of some equations, allowing convergence in very short time. These equations demonstrated good correlation between experiments and simulation of breakthrough performance of the carbon canister.
\end{abstract}

\section{Keywords}

Simulation, Canister, Activated carbon, Adsorption, Diffusion, $n$-Butane

\section{Background of the Research}

Automotive gasoline fuel contains many highly volatile components, so the amount of gasoline that evaporates from the fuel storage and supply system increases with the air and engine temperature. The major volatile components of gasoline are hydrocarbons, such as $n$-butane, pentane, and propane. These hydrocarbons are evaporated by the heat from the outside air when a vehicle is parked for a long period of time and are also emitted from the fuel tank during refueling1). These volatile fuel gases are known to have toxic effects on the human body ${ }^{2)}$ 4). For this reason, fuel emissions regulations have been introduced to control and regulate the emissions of such components. Therefore, modern vehicles are equipped with evaporation loss control devices (ELCD) that prevent the evaporation of gasoline components and are important in preventing toxic emissions into the atmosphere. These devices include activated carbon that is intended to adsorb the volatile components, and the containers filled with activated carbon are called carbon canisters (or simply canisters). A schematic drawing of an ELCD is shown in Fig. 1.

The difference in daytime and nighttime temperatures

\footnotetext{
* To whom correspondence should be addressed.

* E-mail: kazunari.sato@jp.mahle.com
}

causes pronounced changes in internal pressure due to the volatile fuel components inside the fuel tank, and require measures to prevent tank damage by removing such fuel components from the tank, but not allowing leakage into the atmosphere. The ELCD based on activated carbon canisters that adsorb volatile fuel gas prevent the emission of such gases into the atmosphere when a vehicle is stationary. Subsequently, when the vehicle is being driven, some of the air that is sucked into the air intake system via the intake manifold or the like is circulated through the canister. In this way, the volatile fuel components adsorbed by the activated car-

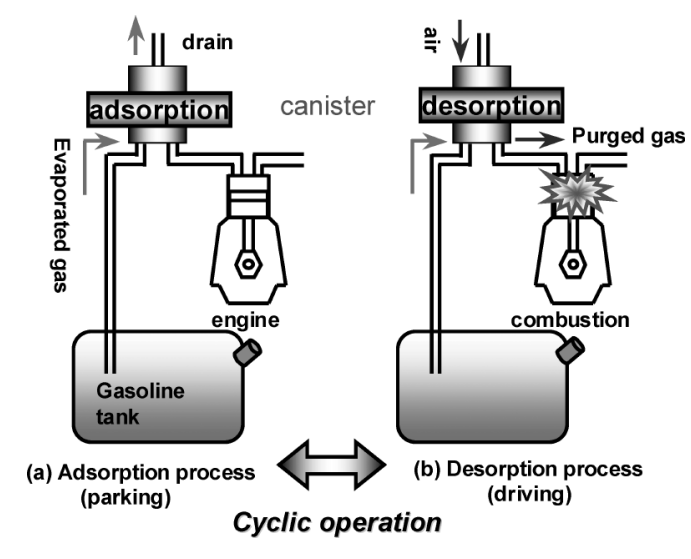

Fig. 1 Schematic Drawing of ELCD Working System 


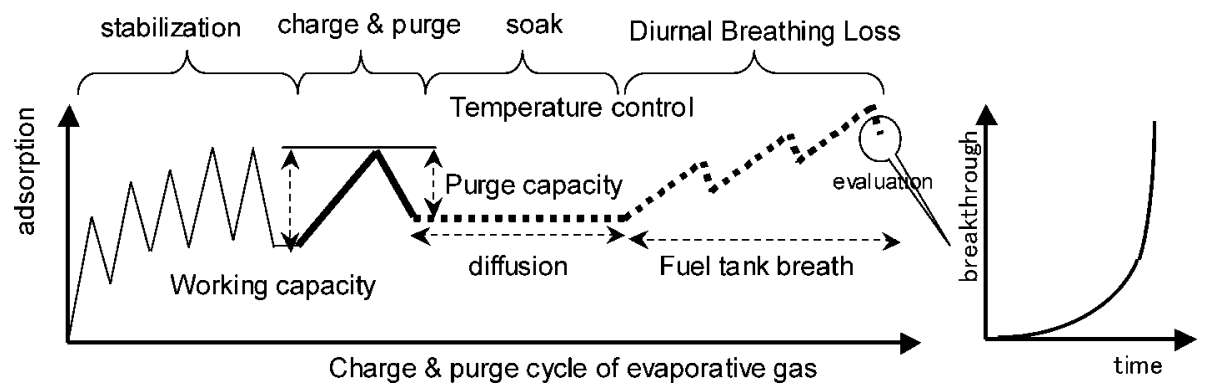

Fig. 2 Standard for Canister Performance Evaluation under U.S. Law

bon bed are drawn into the engine cylinders and burned, thus forming a closed system.

However, the ELCD canister does not actually reduce emissions to zero due to the breakthrough phenomenon that occurs during the day and night breathing loss process called diurnal breathing loss (DBL). Canister breakthrough is thought to be caused by fuel components that are not completely desorbed during the desorption process. These components collect on the drain port side through migration by diffusion during the soak process and then escape into the atmosphere during the DBL process. The procedure for evaluating the breakthrough performance of canisters according to U.S. regulations is shown in Fig. 2.

Possible measures to solve this problem will require both experimental evaluation of canister performance and analysis of the phenomena, and analysis technology and computer simulations to predict the characteristics of the devices and phenomena. Optimum use of computer simulation technology should allow identification of the movement of gas within the canister and quantitative understanding of the adsorption and desorption phenomena that are difficult to measure experimentally. However, no published studies have managed to reproduce the canister breakthrough phenomena using computer simulations that factor in heat transfer and convection, as well as mass transfer due to diffusion.

The present research was intended to develop computer simulation technology and to quantify the mass transfer phenomenon during the series of adsorption, desorption, soak, and DBL processes to resolve and control the problem of canister breakthrough.

\section{Simulation of Adsorption and Desorption Processes}

\section{1. Activated Carbon Characteristics}

The process of purging the adsorbed fuel gas in a canister mounted on an actual vehicle involves the passthrough of large amounts of air and atmospheric water vapor. The presence of this water vapor may affect the high performance activated carbon actually used to adsorb the volatile gasoline components. Therefore, the adsorption equilibrium characteristics

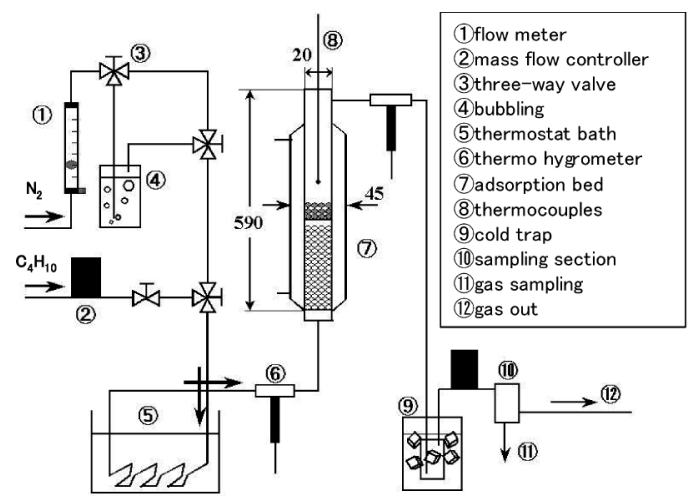

Fig. 3 Schematic Diagram of Experimental Device

were examined using a binary system with water vapor and $n$-butane, which is the major volatile component of gasoline, using nitrogen as the carrier gas for this experiment. The schematic diagram of the experimental device is shown in Fig. 3 .

In this experiment, the molar ratio of the sum of the flow rates of nitrogen, $n$-butane, and water vapor was held constant by changing the flow rates of these three gases while the carbon filled tube was maintained at a constant temperature of $303 \mathrm{~K}$. The equilibrium adsorption obtained with this binary component system and the equilibrium adsorptions for $n$-butane and water vapor obtained from single-component experiments were plotted in relation to the molar fraction of $n$-butane. This graph is shown in Fig. 4.

The results showed that the equilibrium adsorption of $n$-butane in the single-component system was nearly equal to that obtained from the binary system adsorption experiment within the margin of error. Furthermore, this finding was true over the entire range of molar fractions of $n$-butane. The adsorption equilibrium of water vapor obtained from the binary system adsorption experiment was lower than that obtained from the single-component system experiment. Therefore, in a system containing both $n$-butane and water vapor, adsorption of $n$-butane by the activated carbon is favored and the adsorption of water vapor is inhibited. Therefore, the effect of water vapor can be ignored for the purpose of calculating adsorption and desorption. 


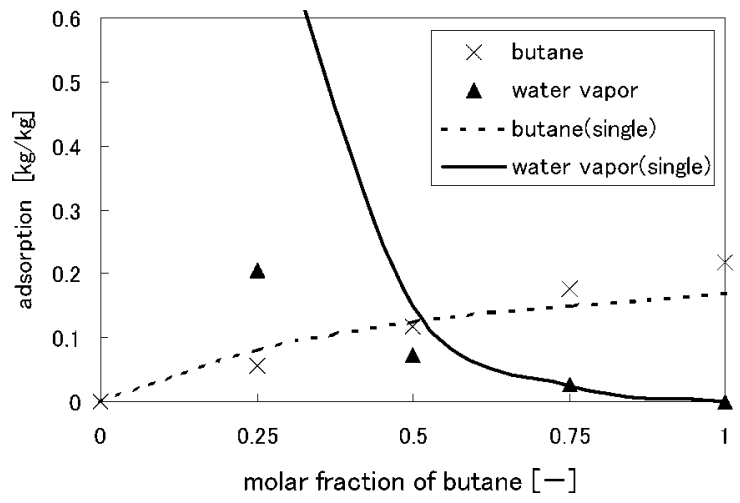

Fig. 4 Equilibrium Adsorption Curves for Single and Binary Systems

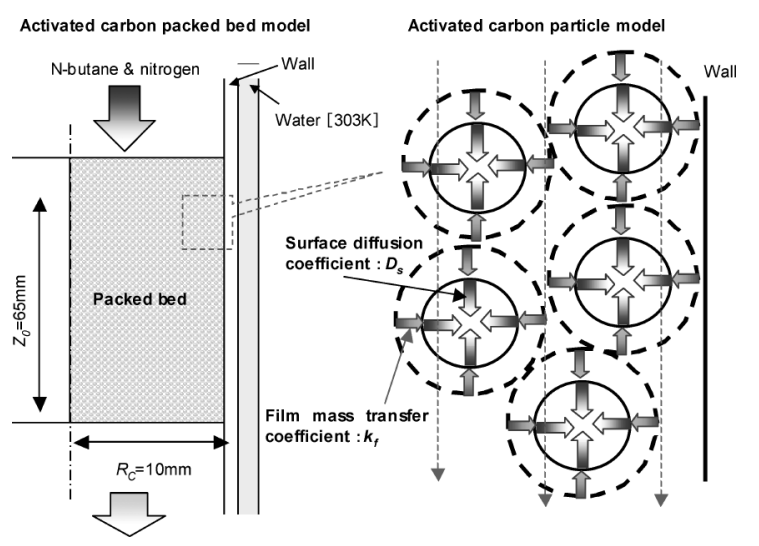

Fig. 5 Schematic Diagram of Transport of $n$-Butane in Packed Bed

\section{2. Adsorption and Desorption Simulation}

The experiments described in the previous section 2. 1. showed that the effect of water vapor can be ignored. Therefore, adsorption and desorption by activated carbon with $n$-butane as the single component and nitrogen gas as the carrier provides a good model to identify the adsorption and desorption phenomena within the canister. A schematic diagram for the analysis model used to simulate the activated carbon filled tube is shown in Fig. 5.

The simulation of the heat and mass transfer phenomena inside the carbon filled tube was created based on the following assumptions: all activated carbon particles are spherical with the same diameter, and are packed uniformly into the bed; the gas that flows through and in the vicinity of the particles remains at the same temperature; and the mass transfer within the particles is dominated by the film mass transfer resistance and surface diffusion resistance of the particle surface.

Based on these assumptions, the fundamental equations for heat and mass transfer in the activated carbon bed during adsorption are as follows.

Equation of mass balance within the activated carbon
Table 1 Experimental Conditions and Properties for Simulation

\begin{tabular}{ccccc}
\hline$r[\mathrm{~m}]$ & $k[\mathrm{~W} / \mathrm{m} / \mathrm{K}]$ & $\varepsilon[-]$ & $\rho_{\mathrm{B}}\left[\mathrm{kg} / \mathrm{m}^{3}\right]$ & $C_{\mathrm{p}}[\mathrm{J} / \mathrm{kg} / \mathrm{K}]$ \\
\hline $196 . \mathrm{E}-06$ & 0.14 & 0.618 & 297.0 & 837.0 \\
\hline
\end{tabular}

bed:

$$
u \frac{\partial C}{\partial Z}+\varepsilon \frac{\partial C}{\partial \theta}+\rho_{\mathrm{A}} \frac{\partial \bar{q}}{\partial \theta}=0
$$

Equation of mass balance within the activated carbon particles:

$$
\frac{\partial q}{\partial \theta}=D_{\mathrm{S}}\left(\frac{\partial^{2} q}{\partial r^{2}}+\frac{2}{r} \frac{\partial q}{\partial r}\right)
$$

Equation of heat balance within the activated carbon bed:

$$
\begin{gathered}
\rho_{\mathrm{B}} c_{\mathrm{P}} \frac{\partial T}{\partial \theta}=k\left(\frac{\partial^{2} T}{\partial Z^{2}}+\frac{\partial^{2} T}{\partial R^{2}}+\frac{1}{R} \frac{\partial T}{\partial R}\right)+ \\
\rho_{\mathrm{f}} c_{\mathrm{PF}} u \frac{\partial T}{\partial Z}+\rho_{A} \Delta H \frac{\partial \bar{q}}{\partial \theta}
\end{gathered}
$$

The properties of the activated carbon used in the simulation are shown in Table 1.

The overall adsorption rate of activated carbon particles is known to be determined by the difference in the concentrations between the particles and the fluid, and also by two types of resistance: the film mass transfer resistance (film diffusion) of the surface of the activated carbon particles and the diffusion resistance toward the interior of the pores (surface diffusion) ${ }^{5}$. The surface diffusion coefficient $D_{\mathrm{S}}$, which is used in the equation of mass balance within the activated carbon particles, is known to be dependent on the diameter of the activated carbon particles ${ }^{6}$. Therefore, a mixture of nitrogen and $n$-butane gas was used under flow rate conditions that allow the film mass transfer resistance that builds up around the surface of the adsorbent to be ignored. This causes the activated carbon bed to adsorb only $n$ butane. The actual adsorption rate of $n$-butane into the activated carbon was then measured and the $D_{\mathrm{S}}$ value obtained from these experiment results and from curve fitting was used for this simulation.

The conditions for the experiment were as follows, adsorption temperature $303 \mathrm{~K}$, amount of activated carbon $1.0 \mathrm{E}-3 \mathrm{~kg}$, and $n$-butane concentration $4.76 \%$. The adsorption experiment was performed by changing the total gas flow rate from 1.05 to $1.47 \mathrm{~L} / \mathrm{min}$, and then to $1.68 \mathrm{~L} / \mathrm{min}$. The results of the experiment are shown in Fig. 6. The initial adsorption rate increased in accordance with the rise in flow rates, but was nearly the same between the flow rates of $1.68 \mathrm{~L} / \mathrm{min}$ and $1.47 \mathrm{~L} / \mathrm{min}$, indicating the maximum $n$-butane adsorption rate of activated carbon. Based on the measured adsorption rate, the surface diffusion coefficient was calculated by comparison to the adsorption rate obtained from the simulation using the surface diffusion co- 


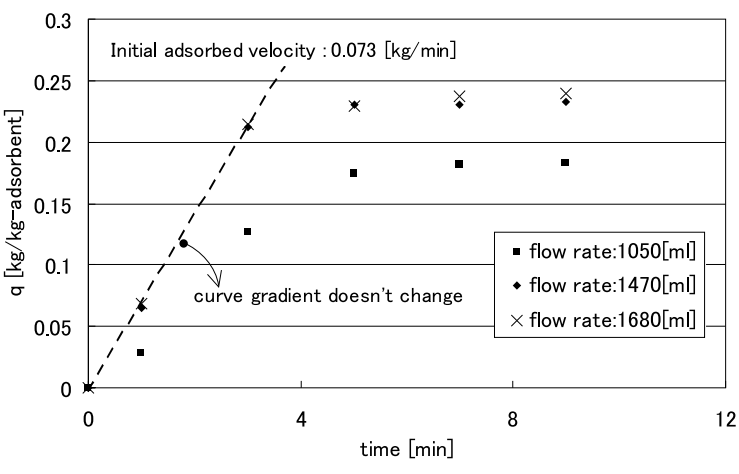

Fig. 6 Adsorption Curves of $n$-Butane for Adsorption Velocity Evaluation

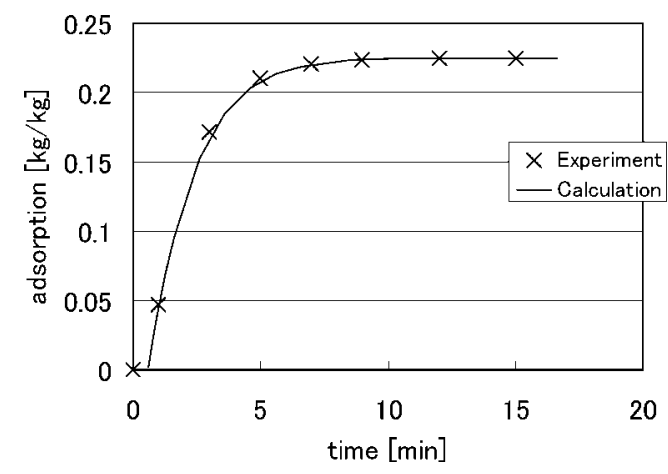

Fig. 7 Adsorption Curves of $n$-Butane Comparison between Experiment and Calculation

efficient as a curve fitting parameter. The curve fitting results obtained at a flow rate of $1.68 \mathrm{~L} / \mathrm{min}$ are shown in Fig. 7.

The experimental and simulation results corresponded closely, confirming that the adsorption model assumptions, including the diffusion coefficient obtained after curve fitting, were appropriate. Therefore, a method for simulating gas diffusion within the activated carbon bed was developed based on this model.

\section{Simulation of Soak Process}

\section{1. Experimental Diffusion of $\boldsymbol{n}$-Butane within the Activated Carbon Bed}

An experiment was performed using a binary system of $n$-butane and nitrogen to evaluate gas diffusion within the activated carbon bed during the soak process. The duration and amount of $n$-butane breakthrough due to migration by diffusion caused by the concentration gradient in the activated carbon bed were measured. The rate of $n$-butane migration by diffusion within the activated carbon bed was then identified from the results of curve fitting.

The experimental device consisted of a stainless steel cylindrical container divided into three chambers (A, B, and $\mathrm{C}$ ) by gates that could be opened and closed elec-

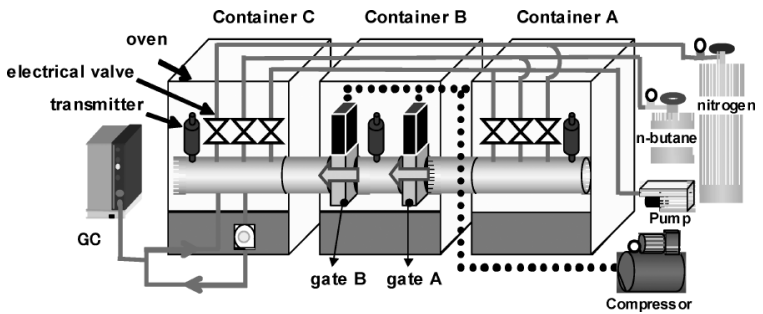

Fig. 8 Schematic Drawing of Experimental Device to Analyze Gas Diffusion

tronically. The entire device was housed inside a thermostat bath so that the experiment could be performed under constant temperature conditions. Furthermore, the equipment allowed measurement of the amount of $n$-butane passing between each of the containers. A schematic drawing of the experiment device is shown in Fig. 8.

Container B was filled with activated carbon and equilibrium adsorption of $n$-butane was performed at $313 \mathrm{~K}$ under atmospheric pressure. Gate B was opened for a period of $1000 \mathrm{~s}$. Container $\mathrm{C}$ was filled with nitrogen at atmospheric pressure for diffusion with $n$ butane in container B. The concentration of the $n$ butane that migrated from container $\mathrm{B}$ to $\mathrm{C}$ was measured $1000 \mathrm{~s}$ after the opening of gate $\mathrm{B}$.

\section{2. Diffusion Simulation}

Migration of $n$-butane within the activated carbon bed during the soak process is thought to be the result of the simultaneous occurrence of surface diffusion from the activated carbon particles, molecular diffusion within the voids, and adsorption and desorption. However, since investigation of these phenomena individually is extremely difficult experimentally, the behavior was considered as a comprehensive diffusion phenomenon, and the study targeted calculation of the effective diffusion coefficient of the $n$-butane in the activated carbon bed.

The basic equations for the binary diffusion phenomenon in the activated carbon bed are as follows.

Equation of mass balance within the activated carbon bed:

$$
\varepsilon \frac{\partial C}{\partial \theta}+\frac{\partial}{\partial X_{i}}\left(C u_{i}+D_{\mathrm{E}} \frac{\partial C}{\partial X_{i}}\right)+\rho_{\mathrm{A}} \frac{\partial \bar{q}}{\partial \theta}=0
$$

Momentum conservation equation within the activated carbon bed:

$$
\varepsilon \frac{\partial C u_{i}}{\partial \theta}+\frac{\partial}{\partial X_{i}}\left(C u_{i} u_{j}-\tau_{i j}\right)+\frac{\partial P}{\partial X_{i}}=0
$$

Migration of mass by diffusion within the activated carbon bed obeys Fick's Law, so can be expressed using the effective diffusion coefficient $D_{\mathrm{E}}$ and the migration direction distance $X_{i}$ through the equation: $D_{\mathrm{E}}\left(\partial^{2} C / \partial X_{i}{ }^{2}\right)$

Details of the calculation conditions, such as other equations and coefficients related to adsorption and de- 


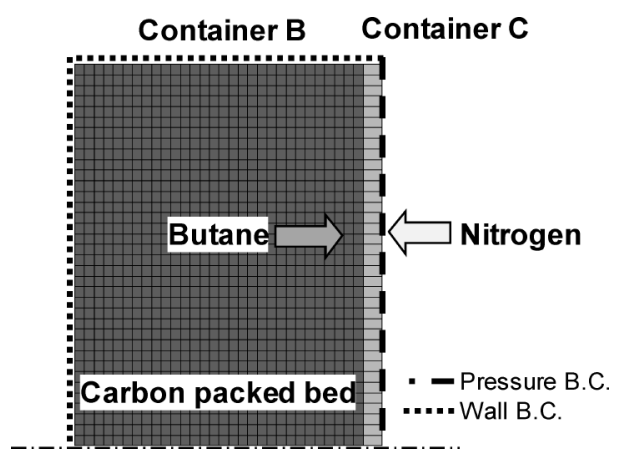

Fig. 9 Schematic Drawing of Calculation Model to Analyze Gas Diffusion

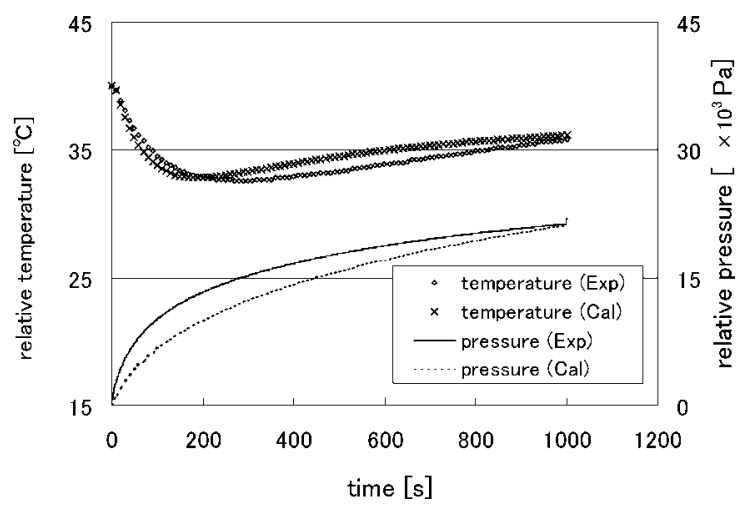

Fig. 10 Profiles of Relative Temperature and Pressure

sorption, were described in Section 2.

Since solving the momentum conservation equation increases the calculation time, the migration rate of the $n$-butane within container $\mathrm{C}$ was assumed to be large in comparison to the migration rate within the activated carbon bed, and, therefore, container $\mathrm{C}$ was not modeled. Therefore, to calculate the mass migration at the boundary between containers B and C with sufficient accuracy, only one layer of a computational grid representing container $\mathrm{C}$ was modeled at the boundary plane. This calculation model is shown in Fig. 9.

The initial conditions for the calculation were as follows. Container B was used to achieve equilibrium adsorption of $n$-butane at $313 \mathrm{~K}$ under atmospheric pressure. Container $\mathrm{C}$ was filled with nitrogen at $313 \mathrm{~K}$ under atmospheric pressure. Curve fitting was then performed under these conditions with the effective diffusion coefficient as a variable. Using a test specimen of the activated carbon bed with $0.03 \mathrm{~m}$ length, the pressure changes in container $\mathrm{C}$ and the temperature changes within the activated carbon bed were measured from the initial state until gate B had been open for $1000 \mathrm{~s}$. These measurements were then compared to the calculation results as shown in Fig. 10.

The calculation results were confirmed to correspond to the experimental results. Therefore, the curve fitting was similarly performed for the pressure changes in

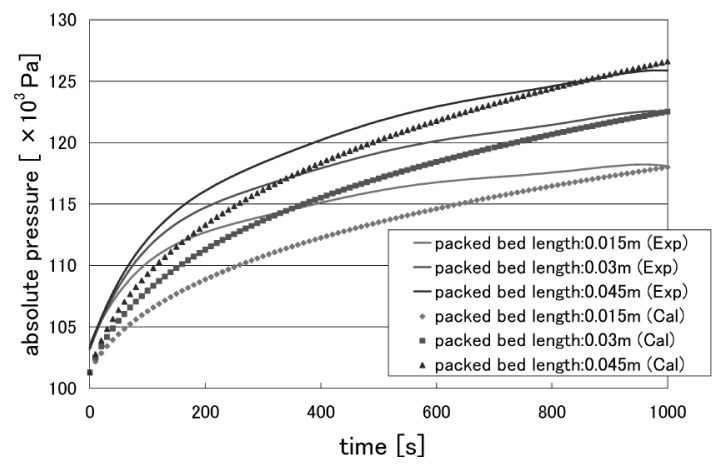

Fig. 11 Profiles of Relative Pressure in Container C

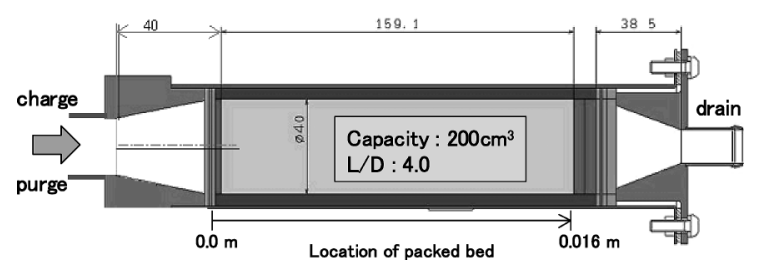

Fig. 12 Schematic Drawing of Experimental Device to Evaluate Breakthrough Gas

container $\mathrm{C}$ with activated carbon bed lengths of $0.015 \mathrm{~m}$ and $0.045 \mathrm{~m}$. The pressure changes in container $\mathrm{C}$ were recorded for a period of $1000 \mathrm{~s}$ after gate B was opened. The data obtained from the experiment and the calculations are compared in Fig. 11. The results show that the model of the activated carbon bed provided the same data as the experiment results for the pressure changes in container $\mathrm{C}$ at all bed lengths, and could predict the effective diffusion coefficient of $n$-butane within the activated carbon bed. Therefore, these results were used to simulate the canister breakthrough phenomenon of the remaining adsorption gas after the soak process during the DBL process.

\section{Simulation of DBL Process}

\section{1. Breakthrough Analysis by DBL Experiment}

The breakthrough phenomenon of the DBL process is strongly influenced by the state of residual adsorption before the gas flows in the carbon packed bed from the gasoline $\operatorname{tank}^{7), 8)}$. Therefore, to examine the DBL breakthrough phenomenon after the soak process is finished, a simplified model was used to perform an adsorption breakthrough experiment. A schematic drawing of the experimental model is shown in Fig. 12.

A sectional experimental device was designed with partitions that divide the activated carbon bed into four portions at intervals where $L / D=1$. This allows the amount of remaining adsorption (derived from the mass of the device) after the completion of each process to be measured in each portion of the activated carbon bed. The device was immersed in a tank of water and the 
Table 2 Boundary Conditions of DBL Simulation to Study Relationship between Soak Time and Breakthrough Amount

\begin{tabular}{lcccc}
\hline \multicolumn{1}{c}{ Process } & Gas/Bulk temp. & Humidity & Mass flow & Test time \\
\hline (1) Adsorption & $25^{\circ} \mathrm{C} / 25^{\circ} \mathrm{C}$ & $40 \% \mathrm{RH}$ & $0.04 \mathrm{~kg} / \mathrm{h}(50 \mathrm{vol} \% \mathrm{butane})$ & $0.002 \mathrm{~kg} \mathrm{~B} . \mathrm{T}$. \\
(2) Soak & $-/ 25^{\circ} \mathrm{C}$ & - & - & $6 \mathrm{~h}$ \\
(3) Desorption & $25^{\circ} \mathrm{C} / 45^{\circ} \mathrm{C}$ & $40 \% \mathrm{RH}$ & $3.0 \mathrm{~L} / \mathrm{min}($ nitrogen $)$ & $1.67 \mathrm{~h}$ \\
(4) Soak & $-/ 25^{\circ} \mathrm{C}$ & - & - & $1,24,36 \mathrm{~h}$ \\
(5) $\mathrm{DBL}$ & $25^{\circ} \mathrm{C} / 25^{\circ} \mathrm{C}$ & $40 \% \mathrm{RH}$ & $0.04 \mathrm{~kg} / \mathrm{h}(50 \mathrm{vol} \%$ butane $)$ & $0.63 \mathrm{~h}$ \\
\hline
\end{tabular}

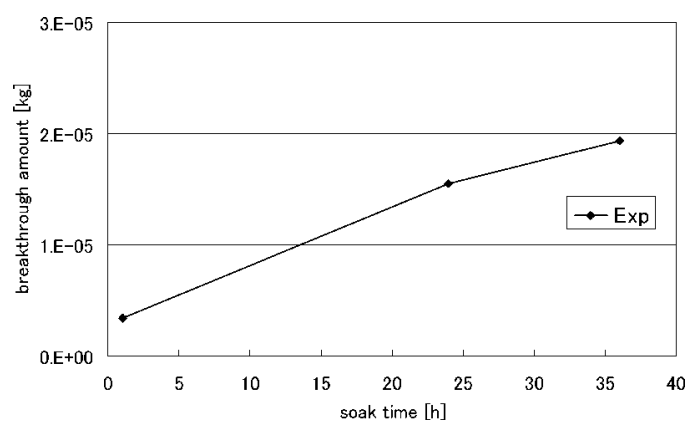

Fig. 13 Breakthrough Curve of $n$-Butane in DBL Process

water temperature was controlled. The temperature and humidity of the gas in the device were measured with a thermo-hygrometer located in the gas supply circuit. The experiment conditions for each of the processes are shown in Table 2.

The measured amounts of breakthrough in the DBL process (5) were plotted according to the soak times in the soak process (4) as shown in Fig. 13. The breakthrough in the DBL experiment increased in proportion to the soak time. The concentration of the breakthrough gas was thought to increase due to migration of highly concentrated gas by diffusion to the drain port side during the soak process. In other words, the distribution of the remaining adsorption from each process is an important factor in determining the final amount of breakthrough.

\section{2. Breakthrough Simulation}

Next, the effect of the mounting orientation of the canister was considered. A buoyancy term was added to the momentum conservation equation and a threedimensional model capable of calculating natural convection due to gravity were used for simulation by creating a $3 \mathrm{D}$ grid model that took symmetry into consideration. The calculation conditions reproduced processes (1) to (5) in Section 4. 1. To rigorously solve the pressures and densities within the computational space, $n$-butane and nitrogen were considered as compressible gases. The calculation model and boundary conditions for calculating the adsorption process are shown in Fig. 14.

The rigorous solution for the heat balance was created by establishing a heat transfer resistance equivalent to that of the 1-mm thick plastic case at the wall surface boundary. The heat transfer was then solved with the

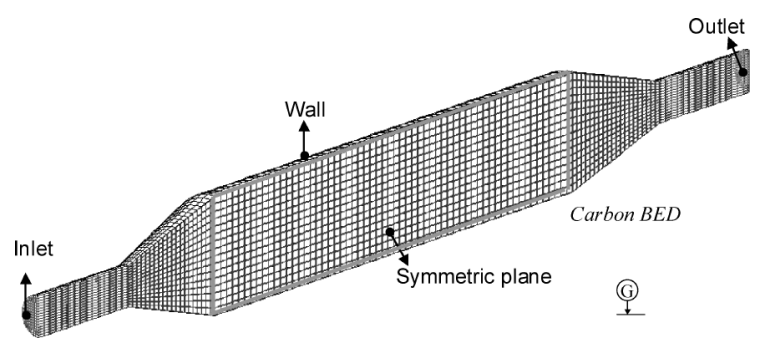

Fig. 14 Schematic Drawing of Calculation Model to Evaluate Breakthrough Gas (adsorption process)

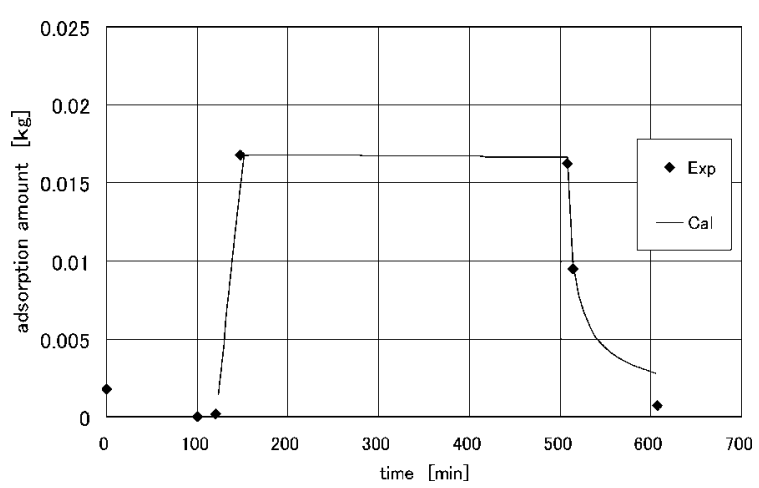

Fig. 15 Adsorption Curves of $n$-Butane through DBL Process

outer wall at a constant temperature of $298 \mathrm{~K}$. The curve for the calculated adsorption amount is shown in Fig. 15. The changes in the adsorption amount from adsorption to the desorption qualitatively matched the experimental values.

\section{3. Verification of Analysis}

The experimental model in Fig. 12 was used to investigate the series of processes up to the DBL process (during which the evaluation conditions changed) to confirm the appropriateness of the methods described from Section 2. Consistency with the simulations was confirmed, but the atmospheric temperature was managed by placing the experimental device into a thermostat bath. The experiment conditions for each process are shown in Table 3.

A simple DBL experiment was then performed to measure the breakthrough amount. The simulation was performed under the same conditions and the change in the adsorption amount was compared to the experimental results. The experimental values for the gas breakthrough amounts were compared to the 
Table 3 Boundary Conditions of DBL Simulation along Regulation

\begin{tabular}{lcccc}
\hline \multicolumn{1}{c}{ Process } & Gas/Bulk temp. & Humidity & Mass flow & Test time \\
\hline (1) Adsorption & $25^{\circ} \mathrm{C} / 25^{\circ} \mathrm{C}$ & $40 \% \mathrm{RH}$ & $0.015 \mathrm{~kg} / \mathrm{h}(50$ vol\% butane) & $0.002 \mathrm{~kg} \mathrm{B.T.}$ \\
(2) Soak & $-/ 25^{\circ} \mathrm{C}$ & - & - & $16 \mathrm{~h}$ \\
(3) Desorption & $25^{\circ} \mathrm{C} / 45^{\circ} \mathrm{C}$ & $40 \% \mathrm{RH}$ & $13.0 \mathrm{~L} / \mathrm{min}$ (nitrogen) & $0.0025 \mathrm{~kg}$ remained \\
(4) DBL & $25^{\circ} \mathrm{C} / 25^{\circ} \mathrm{C}$ & $40 \% \mathrm{RH}$ & $0.00225 \mathrm{~kg} / \mathrm{h}(76$ vol\% butane $)$ & $6 \mathrm{~h}$ \\
\hline
\end{tabular}

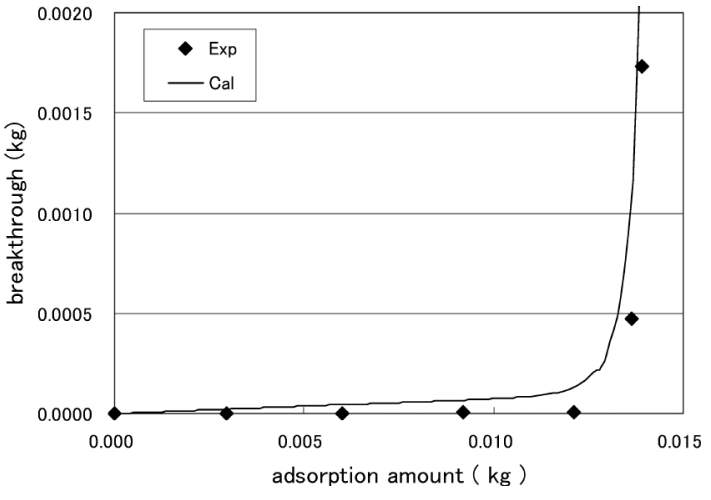

Fig. 16 Breakthrough Curves in DBL Process

amounts of adsorption during the DBL process as shown in Fig. 16. The changes in adsorption amount and breakthrough corresponded between the simulation and the experiment. Therefore, the simulation was confirmed to reproduce the breakthrough phenomenon.

\section{Simplification of the Simulation}

\section{1. Calculations Using the SIMPLE Method}

The calculation time depends on the time intervals $\Delta t$ chosen to confirm the convergence of the calculation during the solution of the differential equations. The number of iterations required increases exponentially with smaller $\Delta t$. Therefore, a method was developed which would not lose the convergence of the calculations even using larger $\Delta t$.

Usually, a momentum conservation equation is used to find the velocity field, and a momentum conservation equation and a mass balance equation are combined to find the pressure field. Iteration is performed to identify the physical values (density and temperature) that satisfy both of these equations, and then the pressure field is found from these physical values using a specific $\operatorname{method}^{9)}$. Conventionally, the pressure-implicit splitoperator (PISO) method ${ }^{10)}$ has been used for these simultaneous equations, and the velocity field and pressure gradient produced in the computational space were solved while modifying the pressure through iteration. In the PISO method, to explicitly solve the flow velocity that changes and is dependent on the calculated pressure, only the change in the physical quantity one step ahead of the current physical quantity can be calculated. Therefore, the physical quantity cannot advance more than one grid interval during a single time step. Therefore, the time interval $\Delta t$ cannot be made larger.

In an effort to resolve this problem, the semi-implicit method for pressure-linked equations (SIMPLE) ${ }^{11)}$ was used to implicitly solve the velocity field and the pressure gradient. Therefore, the current physical quantity had to be predicted from the physical quantity at an unknown time, using a convergence calculation to solve the large-scale determinant at all time steps. This required considerable computer resources to carry out the iteration (exterior iteration). However, the PISO method requires $\Delta t$ to satisfy the stability criterion of each time step, whereas the SIMPLE method allows selection of the value of $\Delta t$ as necessary.

Therefore, the momentum conservation equation can be solved through efficiently discretizing the velocity field and pressure gradient in regard to time and space. The values of the parameters chosen, depending on the problem to be solved, determine the amount of computer processing time that is required. In this simulation, the mass balance within the activated carbon bed is dominated by the change in mass and the attendant change in temperature due to adsorption and desorption. Furthermore, if the superficial velocity of the gas within the canister during the adsorption process is considered, then the Reynolds number is small $(\operatorname{Re}<2000)$. Thus, changes in time for the flow velocity and pressure within the computational space are not likely to be large. The flow of the calculations in the SIMPLE method is well established and a settled steady flow field can be achieved. Therefore, virtually all exterior iterations for the unnecessary time steps can be eliminated without sacrificing the accuracy of the calculation.

Consequently, the SIMPLE method was used to examine suitable values of the time interval $\Delta t$ to shorten the calculation time. This examination was based on the time scale of the change in mass and the attendant change in temperature due to adsorption and desorption, while maintaining the calculation accuracy.

\section{2. Model and Boundary Conditions}

An adsorption simulation was performed to verify the improvement obtained by using the SIMPLE method for the calculation. The model and boundary conditions for this adsorption calculation are shown in Fig. 17. In this case, the gas was treated as an incompressible laminar flow and the concentration was calculated from the mass ratio of nitrogen and $n$-butane. The computational grids were all hexahedrons consisting of the 
normal gas and the porous medium (activated carbon bed). The total number of grids in this model was 18,014 (normal gas 8004 and porous medium 10,010). The calculations were performed using a half model due to the symmetry of the target objects. The physical properties of the model are shown in Table 4 .

\section{3. Examination of Convergence}

To confirm convergence via the simplified calculations in this simulation, the history until the $0.002 \mathrm{~kg}$ breakthrough of $n$-butane in the adsorption process was calculated using the time intervals $\Delta t$ shown in Table 5 . The $n$-butane mass balance was monitored at each time step to examine the optimal $\Delta t$. The calculation times are shown in Table 6. Here, the number of time steps until the calculation was completed depended on the calculation convergence state of each case. Therefore,

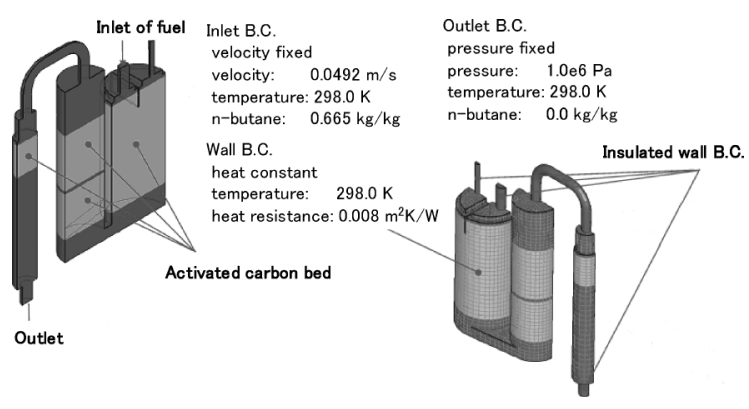

Fig. 17 Schematic Drawing of Calculation Model and Boundary Conditions for Verification

Table 4 Physical Properties of Gas and Activated Carbon

\begin{tabular}{lrccc}
\hline & & Air & $n$-Butane & Carbon bed \\
\hline Density & {$\left[\mathrm{kg} / \mathrm{m}^{3}\right]$} & 1.205 & 2.275 & 367.0 \\
Viscosity & {$[\mathrm{Pa} \cdot \mathrm{s}]$} & $1.78 \mathrm{E}-05$ & $7.51 \mathrm{E}-06$ & - \\
Specific heat & {$[\mathrm{J} / \mathrm{kg} / \mathrm{K}]$} & \multicolumn{2}{c}{1006.0} & 745.0 \\
Heat conductivity $[\mathrm{W} / \mathrm{m} / \mathrm{K}]$ & \multicolumn{2}{c}{0.0256} & 0.14 \\
Void fraction & {$[-]$} & - & - & 0.337 \\
Heat transfer & {$\left[\mathrm{W} / \mathrm{m}^{3} / \mathrm{K}\right]$} & & $1.0 \mathrm{E}+06$ \\
\hline
\end{tabular}

Table 5 Time Step Conditions

\begin{tabular}{cc}
\hline Case name & Time interval $[\mathrm{s}]$ \\
\hline case-1 & 0.01 \\
case-2 & 0.1 \\
case-3 & 1 \\
case-4 & 2 \\
case-5 & 5 \\
\hline
\end{tabular}

the number of calculation steps and the calculation time to complete all those steps are shown, as well as the conversions for time per step and the value for the calculation time calculated in $10 \mathrm{~s}$ of real time (listed as CPU time/10 s).

The changes in adsorption amount are shown in Fig. 18. Notable points in the $n$-butane adsorption amount are the small calculation errors in case- 1 and case-2 (where the time intervals were small) and the fact that the adsorption amount in these two cases were almost identical. Although the time intervals were larger in case- 2 than in case- 1 , there were a large number of steps. By making the time intervals larger, the convergence becomes worse, and so the number of steps increases due to the number of exterior iterations reaching its upper limit. In this type of case, using a smaller time interval leads to a reduction in the calculation time. Furthermore, case- 3 and case- 4 show greater oscillations from midway through the calculation, and that the calculations in these cases are not converging. On the other hand, case- 5 shows no oscillation and has the same characteristic trend as case-1. However, divergence from case- 1 can be seen in case- 5 .

The difference between the mass that flowed out (including adsorption) in relation to the mass that flowed in, and the mass that remained in the space was evaluated as the calculation error at each time $\Delta t$. These results are shown in Fig. 19. A notable point in the calculation error is that the solution oscillates greatly and no mass balance is obtained in case- 3 and case- 4 . On the other hand, even though case-5 has small oscillation

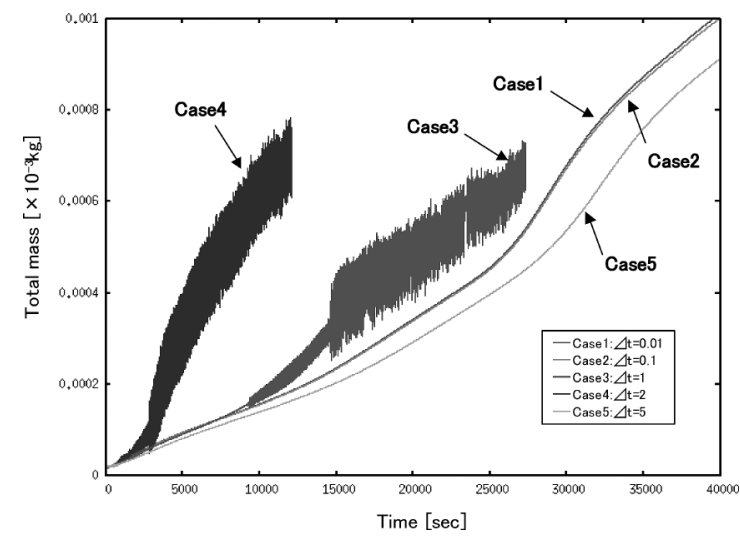

Fig. 18 Profiles of Total Adsorbed $n$-Butane Mass

Table 6 Calculation Time

\begin{tabular}{ccccc}
\hline Case name & Calculation cycle & CPU time [s] & CPU time/cycle [s] & CPU time/10 s [s] \\
\hline case-1 & 199997 & 38324 & 0.192 & 191.6 \\
case-2 & 407864 & 75360 & 0.185 & 18.5 \\
case-3 & 12155 & 7138 & 0.587 & 5.9 \\
case-4 & 13751 & 8238 & 0.599 & 3.0 \\
case-5 & 5859 & 2919 & 0.498 & 1.1 \\
\hline
\end{tabular}




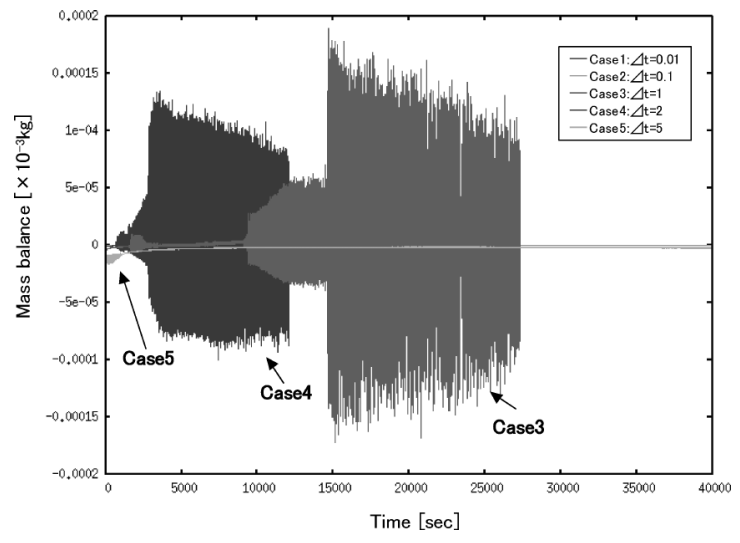

Fig. 19 Profiles of Adsorbed $n$-Butane Mass Balance

during the initial stage of the calculation, loss of balance was not as bad as in case- 3 and case- 4 .

These verification results show that results calculated by the SIMPLE method differed depending on how the time intervals were selected. The results were stable in this simulation when $\Delta t \leq 0.1 \mathrm{~s}$. This time interval is 1000 times larger than the time interval of $\Delta t=$ $0.0001 \mathrm{~s}$ used in the initial simulation as explained in Section 2. Therefore, the calculation time can be reduced to approximately $1 / 1000$ of the previous time. In this way, $\Delta t$ is sensitive to the stability of the convergence calculation solved using the SIMPLE method. Furthermore, by optimizing $\Delta t$ according to the problem that needs to be solved, it is possible to predict the mass migration in an extremely short time.

\section{Summary}

The present study developed a method of simulation for $n$-butane gas adsorption in activated carbon canisters used to adsorb volatile gasoline components. The adsorption heat of the $n$-butane in the activated carbon was calculated based on the adsorption isotherm curve, and the $n$-butane adsorption rate of the activated carbon particles was obtained from curve fitting using experimental values. In addition, the effective diffusion coefficient of the $n$-butane in the activated carbon bed was found by migration experiments and simulations.

Based on this new knowledge, a simplified simulation was developed to reproduce the series of phenomena from the adsorption process to the DBL process. The simulation results showed that the change over time in the adsorption amount of $n$-butane within the activated carbon bed and the distribution of the adsorption amount of $n$-butane at each time were almost completely consistent with the experimental values. Furthermore, the change over time in the breakthrough $n$-butane over the series of processes was also almost completely consistent with the experimental values. Both of these findings were confirmed through calculations that took an extremely short amount of time due to the simplified method.

Analysis of the physical phenomena that occur within the canisters through both experimentation and simulation will help to develop zero evaporative emissions systems for gasoline vehicles and represents an important low cost technology for vehicle producers.

\section{Nomenclatures}

\begin{tabular}{|c|c|c|}
\hline$C$ & : gas density & {$\left[\mathrm{kg} \cdot \mathrm{m}^{-3}\right]$} \\
\hline$c_{\mathrm{P}}$ & : specific heat capacity of packed bed & {$\left[\mathrm{J} \cdot \mathrm{kg}^{-1} \cdot \mathrm{K}^{-1}\right]$} \\
\hline $\mathrm{CpF}_{\mathrm{pF}}$ & : specific heat capacity of fluid & {$\left[\mathrm{J} \cdot \mathrm{kg}^{-1} \cdot \mathrm{K}^{-1}\right]$} \\
\hline$D_{\mathrm{S}}$ & : surface diffusion coefficient & {$\left[\mathrm{m}^{2} \cdot \mathrm{s}^{-1}\right]$} \\
\hline$D_{\mathrm{E}}$ & : effective diffusion coefficient & {$\left[\mathrm{m}^{2} \cdot \mathrm{s}^{-1}\right]$} \\
\hline$\Delta H$ & : heat of adsorption & {$\left[\mathrm{J} \cdot \mathrm{kg}^{-1}\right]$} \\
\hline & : effective thermal conductivity of packed bed & \\
\hline & & {$\left[\mathrm{W} \cdot \mathrm{m}^{-1} \cdot \mathrm{K}^{-1}\right]$} \\
\hline$P$ & : pressure & {$[\mathrm{mmHg}]$} \\
\hline & : adsorbed amount & {$\left[\mathrm{kg} \cdot \mathrm{kg}^{-1}\right]$} \\
\hline $\bar{q}$ & : average adsorbed amount & {$\left[\mathrm{kg} \cdot \mathrm{kg}^{-1}\right]$} \\
\hline & : radial distance from center of packed bed & [m] \\
\hline & : radial distance from center of carbon particle & {$[\mathrm{m}]$} \\
\hline T & : temperature & {$[\mathrm{K}]$} \\
\hline$\Delta t$ & : time interval & \\
\hline$u_{i, j, k}$ & : gas velocity & {$\left[\mathrm{m} \cdot \mathrm{s}^{-1}\right]$} \\
\hline$X_{i, j, k}$ & : cartesian coordinate & [m] \\
\hline$Z$ & : length from the bottom of packed bed & {$[\mathrm{m}]$} \\
\hline \multicolumn{3}{|c|}{$<$ Greeks $>$} \\
\hline & : void fraction of packed bed & {$[-]$} \\
\hline & : apparent density of carbon particle & {$\left[\mathrm{kg} \cdot \mathrm{m}^{-3}\right]$} \\
\hline & : apparent density of packed bed & {$\left[\mathrm{kg} \cdot \mathrm{m}^{-3}\right]$} \\
\hline & : density of fluid gas & {$\left[\mathrm{kg} \cdot \mathrm{m}^{-3}\right]$} \\
\hline & : time & \\
\hline & : viscosity component & {$\left[\mathrm{kg} \cdot \mathrm{m}^{-1} \cdot \mathrm{s}^{-1}\right]$} \\
\hline
\end{tabular}

\section{References}

1) "Countermeasure method of automobiles emission reduction in the future (5th report 2002)," Central Environmental Council, http://www.env.go.jp/council/toshin/t07-h1401/t07h1401-3.pdf (newest access: 2009. 12. 25). “今後の自動車排出ガス低減対策のあり方について (2002 第五次答申), ”中央環境審議会, http://www.env.go.jp/ council/toshin/t07-h1401/t07-h1401-3.pdf（最新アクセス : 2009. 12. 25)

2) Suzuki, T., "Environmental science of atmosphere," Uchidaroukakuho Ltd., (1993), p. 148-151. 鈴木静夫, “大気の環境科学, ”内田老鶴圃, (1993), p. 148-151.

3) Sakai, M., "Story of a carcinogen," Gihoudou Shuppan Ltd., (2001), p. 9-20. 酒井 弥, “発ガン物質の話, ”技報堂出版, (2001), p. 9-20.

4) Society of Air Pollution Situation along Road, "Air pollution situation along road No. 11," Gyousei Corp., Tokyo (2000). 沿道大気污染状況研究会, “道路周辺の大気污染状況 11, ”ぎょうせい, 東京 (2000).

5) Hashimoto, K., Miura, K., “Adsorption Technology Handbook,” NTS Co., Ltd., (1993), p. 429-443. 橋本健治, 三浦孝一, “吸着技術ハンドブック，”NTS 社, (1993), p. 429-447.

6) Prasetyo, I., Do, H. D., Do, D. D., Chem. Eng. Sci., 57, 133 (2002). 
7) Itakura, H., Hyoudou, Y., JSAE Technical Paper Series, 981, 29 (1998).

8) Itakura, H., Kato, N., Kohama, T., Hyoudou, Y., Murai, T., SAE Technical Paper Series, 2000-01-0895 (2000).

9) Ferziger, J. H., Peric, M., "Computational Methods for Fluid Dynamics," Springer Japan Co., (2003), p. 103-173.
10) Issa, R. I., "Solution of the Implicitly Discretized Fluid Flow Equation by Operator Splitting," J. Comput. Phys., 62, (1986), 40.

11) Patankar, S. V., Spalding, D. B., Int. J. Heat Mass Transfer, 15, 1787 (1972).

要旨

\author{
カーボンキャニスターの $n$-ブタン吸脱着現象シミュレーション \\ 佐藤 一成 ${ }^{\dagger 1)}$, 小林 敬幸 $\left.{ }^{2}\right)$ \\ †1)（株）マーレフィルターシステムズ テクニカルセンター, 350-1155 埼玉県川越市下赤坂591 \\ †2) 名古屋大学大学院工学研究科化学. 生物工学専攻, 464-8603 名古屋市千種区不老町
}

自動車の燃料タンクから排出される蒸散燃料ガスには人体に 有害な物質が含まれており，法規制により排出が厳しく制限さ れている。大気中への蒸散ガス放出（破過）を防止する装置で あるカーボンキャニスターは, 内部の活性炭充填層でガスを吸 着することでタンクからの排出を抑制する。本研究では, 自動 車から排出される蒸発燃料ガスの主成分である $n$-ブタンと活 性炭の吸脱着・拡散現象を実験と数值計算から明確にして, 活 性炭層内での物質収支と熱収支の計算式を確立した。この計算
式を用いてキャニスターの性能シミュレーションを行い実測し た破過特性と比較した結果, 良い相関を得ることができ, シ ミュレーションの妥当性を確認した。また, 長時間にわたる過 渡的な現象の計算には膨大な時間が必要となるため, 収支式を 高次の解法により解くことで計算の収束性を格段に高め, 計算 時間を短縮した。これらの結果, いくつかの収支式を組み込ん だ流体解析ツールを用いてカーボンキャニスター内の $n$-ブタ ンの挙動と破過特性を実用的に予測することが可能となった。 